\title{
Monitoring Kekenyalan Tahu Kedelai dengan Sensor Kapasitif Menggunakan Mikrokontroller Berbasis Android
}

\author{
Rizky Putri Nur Laili ${ }^{\# 1}$, Farida Arinie Soelistianto ${ }^{\# 2}$, Nanak Zakaria ${ }^{\# 3}$, *Nurul Hidayati ${ }^{\# 4}$ \\ \# Jurusan Teknik Elektro, Politeknik Negeri Malang \\ Jl. Soekarno Hatta No. 9, Malang, Indonesia \\ ${ }^{1}$ rizkyputri0510@gmail.com \\ 2farida.arinielpolinema.ac.id \\ ${ }^{3}$ nanak_zachepolinema.ac.id \\ ${ }^{4}$ nurulhid8@polinema.ac.id*
}

\begin{abstract}
Abstrak - Tahu memiliki protein nabati kualitas terbaik karena memiliki komposisi asam amino paling lengkap dan diyakini memiliki daya cerna yang tinggi (sebesar $85 \%-98 \%$ ). Menurut SNI 01-3142-1998 dan SII No. 0270-1990 kriteria uji tahu kedelai berdasarkan bau, rasa, warna, penampakan atau tekstur. Ttahu kedelai yang mudah mengalami kerusakan fisik atau tekstur dengan faktor antara lain kadar pH yang tidak sesuai dan penyimpanan yang kurang berakibat tahu menjadi rusak. Oleh karena itu pada penilitian ini diusulkan untuk mengetahui kekenyalan pada tahu kedelai dengan parameter yang diuji adalah tingkat kadar pH pada pembuatan tahu kedelai, suhu penyimpanannya, dan nilai kapasitansi untuk melihat berapa kekenyalan pada tahu dengan sensor kapasitif yang menggunakan prinsip kapasitor. Dimana kapasitor plat sejajar ini merupakan kapasitor yang terdiri dari dua buah plat logam sejajar. Hasil pengujian dari semua sensor di kirim ke dalam database dan akan ditampilkan di halaman pada aplikasi android yang akan memberikan informasi hasil keluaran sensor secara real time kepada pengguna. Berdasarkan hasil pengujian pada sistem ini dengan menggunakan sensor $\mathrm{pH}$ didapatkan nilai $\mathrm{pH}$ berkisar 3-4 yang menandakan kadar $\mathrm{pH}$ yang digunakan sangat bagus untuk dipakai pada pengolahan tahu, pada pH 4.56 dengan penyimpanan pada suhu $29^{\circ} \mathrm{C}$ mendapatkan nilai kapasitansi kekenyalan paling tinggi yaitu sebesar 3.58. Pada pengujian pengiriman data yaitu diperoleh nilai troughtput $4336.217 \mathrm{~b} / \mathrm{s}$ dan nilai delay terkecil $0.017 \mathrm{~ms}$ karena semakin kecil nilai delay maka kualitas pengiriman data akan semakin baik karena tidak akan terjadi keterlambatan pengiriman data.
\end{abstract}

Kata kunci: pH, Suhu, Kapasitif, Android

Abstract-Tofu has the best quality vegetable protein because it has the most complete amino acid composition and is believed to have high digestibility (85\% -98\%). According to SNI 01-3142-1998 and SII No. 0270-1990 testing criteria for soy tofu based on smell, taste, color, appearance or texture. Tofu soybeans are prone to physical or texture damage due to factors such as inappropriate $\mathrm{pH}$ levels and insufficient storage which results in damaged tofu. Therefore in this study it is proposed to determine the elasticity of soy tofu with the parameters tested are the $\mathrm{pH}$ level in the manufacture of soy tofu, the storage temperature, and the capacitance value to see how thick the tofu is with a capacitive sensor using the capacitor principle.
Where the parallel plate capacitor is a capacitor consisting of two parallel metal plates. The test results of all sensors are sent to the database and will be displayed on the page on the Android application which will provide real time sensor output information to the user. Based on the results of testing on this system using a pH sensor, the $\mathrm{pH}$ value is around 3-4 which indicates that the $\mathrm{pH}$ level used is very good for use in tofu processing, at $\mathrm{pH} 4.56$ with storage at $29^{\circ}$ C the highest elastic capacitance value is 3.58. In testing data delivery, the troughtput value is 4336,217 $\mathrm{b} / \mathrm{s}$ and the smallest delay value is $0.017 \mathrm{~ms}$ because the smaller the delay value, the better the quality of data transmission because there will be no delay in sending data.

Keywords: pH, Temperature, Capacitive, Andoid

\section{Pendahuluan}

Makanan merupakan kebutuhan dasar manusia sebagai sumber energi untuk menjalankan aktifitas fisik maupun biologis dalam kehidupan sehari-hari. Indonesia merupakan salah satu Negara yang memiliki banyak keaneka ragaman dalam bidang makanan [1][2]. Makanan yang dikonsumsi oleh tubuh harus memiliki nilai gizi yang optimal dan lengkap. Salah satunya adalah tahu, Tahu memiliki protein nabati kualitas terbaik karena memiliki komposisi asam amino paling lengkap dan diyakini memiliki daya cerna yang tinggi (sebesar 85\% 98\%). Tingkat konsumsi tahu yang tinggi di Indonesia disebabkan oleh nutrisinya yang cukup tinggi, khususnya protein, harganya relatif terjangkau, praktis, dan mudah didapat. Proses pembuatan tahu dimulai dengan koagulasi protein yang terkandung dalam susu kedelai, yang dilanjutkan dengan pengepresan sehingga hasilnya menyerupai keju lunak yang berwarna putih. Menurut SNI 01-3142-1998 dan SII No. 02701990 kriteria uji tahu kedelai berdasarkan bau, rasa, warna, penampakan atau tekstur. Oleh karena itu Tahu kedelai yang mudah mengalami kerusakan fisik atau tekstur dengan faktor antara lain kadar $\mathrm{pH}$ yung tidak sesuai dan penyimpanan yang kurang berakibat tahu menjadi lembek, padat atau rusak. Pada penelitian sebelumnya yang meneliti tentang "Pada penelitian sebelumnya yang dilakukan oleh [3] dimana pada penelitian ini 
untuk pengendalian kadar keasaman pada pengendapan tahu dengan Rentang agar kualitas tahu yang dibuat maksimal.

Oleh karena itu pada penilitian ini dibangunlah sistem untuk mengetahui berapa tingkat kadar $\mathrm{pH}$ keasaman yang baik untuk pembuatan tahu dengan memanfaatkan sensor $\mathrm{Ph}$, sensor suhu untuk menentukan suhu penyimpanan dan untuk melihat berapa nilai kapasitansi kekenyalan pada tahu dengan memanfaatkan sensor kapasitif yang menggunakan prinsip kapasitor dimana kapasitor plat sejajar merupakan kapasitor yang terdiri dari dua buah plat logam yang disusun secara paralel dan dipisahkan oleh jarak sebesar d [4] dimana pada penelitian ini tahu kedelai yang diuji akan menjadi bahan dielektrik.

Dengan memanfaatkan Arduino Uno sebagai pemroses masukan dari semua sensor, seluruh informasi yang didapatkan oleh sensor akan diproses dan dikirimkan data nya melalui jaringan internet secara wireles dengan menggunakan modul ESP8266 dalam hal ini data keluaran nilai dari pengujian sensor dapat ditampilkan pada smartphone yang berupa aplikasi [5-7]. Jadi user atau pengguna dapat mengetahui nilai dari keluaran sensor tersebut melalui aplikasi android. Diharapkan menjadi sebuah sistem yang dapat membantu dalam mengetahui berapa tingkat tekstur kekenyalan tahu kedelai yang baik untuk diolah oleh konsumen.

\section{Metode Penelitian}

Penelitian ini digunakan untuk mengetahui permasalahan yang sedang dilakukan, yaitu tentang peran pemanfaatan sensor pH, sensor suhu dan sensor kapasitif. Sebagai uji deteksi dari keluaran sensor $\mathrm{pH}$, suhu dan kapasitif berdasarkan kekenyalan tahu kedelai. Metode penelitian ini termasuk dalam research and development $(\mathrm{R} \& \mathrm{D})$.

\section{A. Tahapan Penelitian}

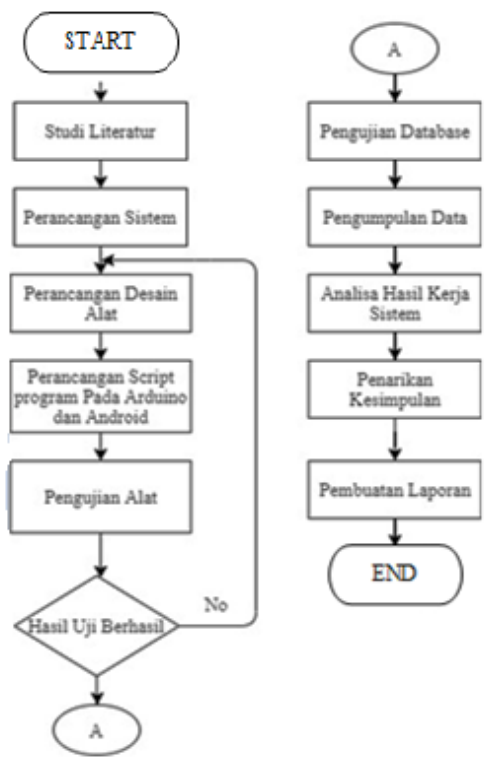

Gambar 1. Tahapan Penelitian
- Tahapan pertama yaitu melakukan studi literatur mengenai teori kekenyalan tahu kedelai, sensor $\mathrm{pH}$, sensor suhu, sensor kapasitif, Arduino, NodeMCU ESP8266 dan Android. Pada tahap ini mempelajari penggunaan dan karakteristik mengenai sensor dan pemrograman untuk pembuatan sistem.

- Tahap kedua yaitu perancangan sistem mengenai parameter pengujian yang akan diukur pada sistem, berupa parameter $\mathrm{Ph}$, suhu dan kapasitansi.

- Tahap ketiga yaitu perancangan desain sistem kerja dari alat yang akan digunakan. Pada tahapan ini dilakukan perencanaan mengenahi penggabungan Arduino dengan sensor $\mathrm{pH}$, sensor suhu dan sensor kapasitif, NodeMCU ESP8266.

- Tahap keempat yaitu perancangan program script yang digunakan, dimana script dibuata pada Arduino dan Android.

- Tahap kelima yaitu pembuatan sistem yang telah dibuat pada tahap ketiga dan keempat, pengujian ini dilakukan untuk mengetahui hasil pengujian sistem yang telah direncanakan. Jika program mengalami kesalahan maka akan dilakukan troubleshooting supaya program berjalan seperti yang diharapkan dan jika sensor menglami masalah akan dicek ulang terhadap sensor yang bermasalah.

- Tahap keenam yaitu tahap pengujian database, tahap ini digunakan untuk memproses data agar dapat ditampilkan pada Android.

- Tahap ketujuh yaitu tahap pengunpulan data, dimana data yang diperoleh dari pengujian sistem.

- Tahap kedelapan yaitu tahapan analisa hasil nilai pengujian sistem dan perbandingan dari setiap parameter yang didapatkan.

Tahap kesembilan yaitu tahap penarikan kesimpulan dan saran dari hasil penelitian.

\section{B. Blok Diagram Sistem}

Rancangan yang akan dilakukan pada penelitian ini akan ditunjukkan pada Gambar 2.

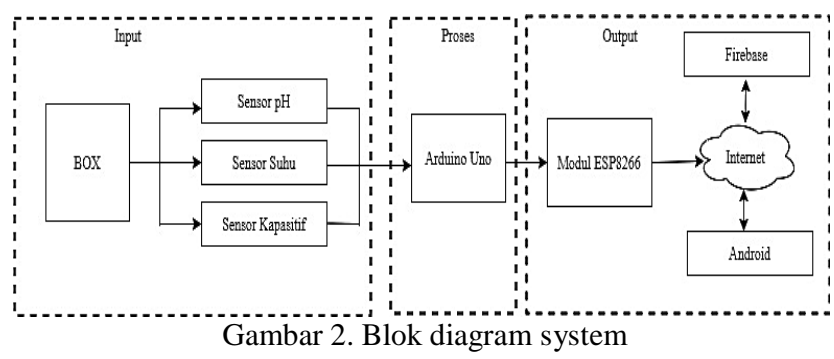

Pada blok input terdiri atas beberapa macam sensor yang memiliki fungsi masing-masing yaitu :

1. Sensor $\mathrm{pH}$

Sensor pH SKU SEN-CB0214 berperan sebagai pembaca nilai kandungan $\mathrm{pH}$ asam pada pembuatan tahu kedelai, dengan 
cara kerja sensor yaitu outputan nilai keluaran sensor $\mathrm{pH}$ berupa tegangan analog yang selanjutnya dikuatkan oleh modul pH tipe 4502C untuk pengkondisi sinyal sehingga terbaca dan diolah pada arduino uno.

\section{Sensor Suhu}

Sensor suhu berperan sebagai pembaca data suhu dari wadah penyimpanan untuk mengetahui pengaruh lama penyimpanan, dengan cara kerja sensor suhu DS18B20 yaitu sensor mengirimkan data digital berupa sinyal pulsa yang mengindikasi suhu tertentu pada sensor dihubungkan resistor $4.7 \mathrm{k}$ ohm sebagai resistir pullup atau penguat sinyal dengan tujuan agar data-data yang diukur dapat terbaca dan tidak berakibat eror kemudian outputan dari sensor akan diterima dan diolah oleh arduino uno.

3. Sensor Kapasitif

Sensor Kapasitif berperan sebagai pembaca data nilai kapasitansi dari kekenyalan tahu kedelai, dengan cara kerja sensor berdasar kan perubahan muatan energi listrik yang dapat disimpan oleh sensor akibat perubahan jarak antar pcb. Terdapat resistor 100k ohm untuk pengosongan nilai keluaran untuk menjadi nol kembali. Selanjutnya nilai kapasitansi yang didapatkan dari pembacaan sensor akan diolah pada arduino uno.

Pada Blok proses terdiri atas sebuah Mikrokontroller Arduino Uno yang bertugas untuk pemroses masukan dari sensor dan mengolah data hasil pembacaan sensor[7-9].

Pada Blok Output terdiri dari komponen yang mendukung untuk proses pengambilan data kekenyalan tahu kedelai dan menampilkan data hasil pembacaan input pada tampilan Android.

\section{Modul Esp8266}

Modul Esp8266 berfungsi sebagai perangkat transmisi data hasil pengolahan Arduino secara wireless antara perangkat sistem dengan Android. Ketika data sensor akan secara terusmenerus di kirim menuju Arduino selanjutnya data yang telah diolah oleh Arduino Uno akan dikirim ke database secara wireless menggunakan modul Esp8266.

2. Android

Android berperan sebagai alat yang digunakan untuk menampilkan text dan grafik hasil data yang diperoleh dari inputan sensor.

\section{Flowchart Sistem Keseluruhan}

Flowchart Sistem pada penelitian ini diperlihatkan pada gambar 3. Pada gambar tersebut menjelaskan flowchart sistem pada keseluruhan

- Saat sistem on, Sistem ini memiliki input berupa data dari sensor $\mathrm{pH}$, suhu dan kapasitif.

- Sensor pH, suhu dan kapasitif akan membaca keluaran dari semua sensor.

- Jika nilai dari sensor tidak muncul akan dilakukan pengujian ulang.
- Sensor Ph, suhu dan kapasitif terhubung langsung ke Arduino yang akan berfungsi untuk mengolah data sensor serta sebagai kontrol jalannya sistem.

Data yang telah diolah akan langsung dikirimkan kepada server firebase yang akan ditampilkan di Android sebagai hasil dari kerja sistem.

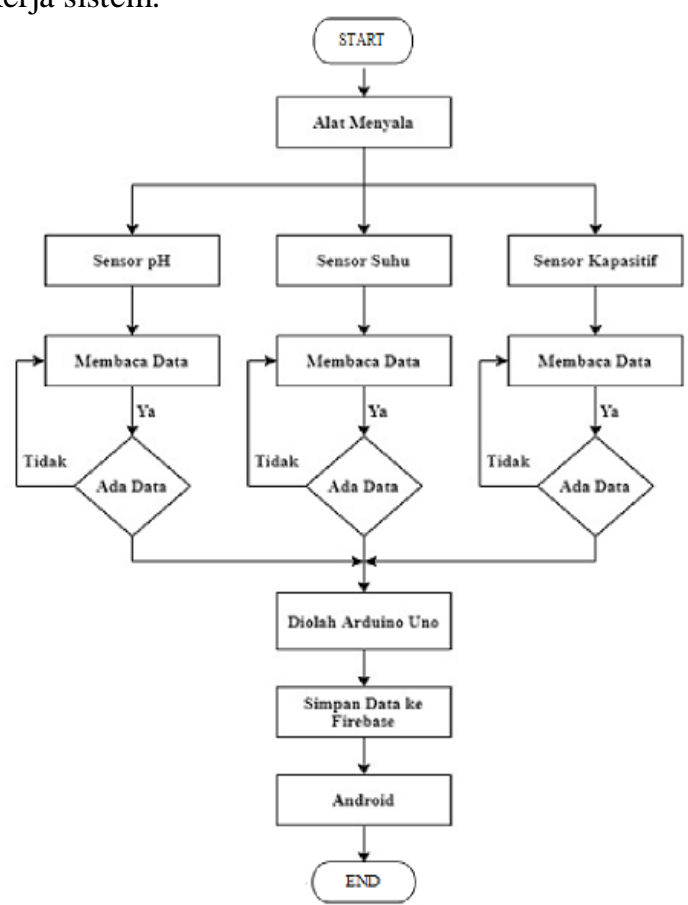

Gambar 3. Flowchart system

Untuk flowchart aplikasi android diperlihatkan pada gambar 4.
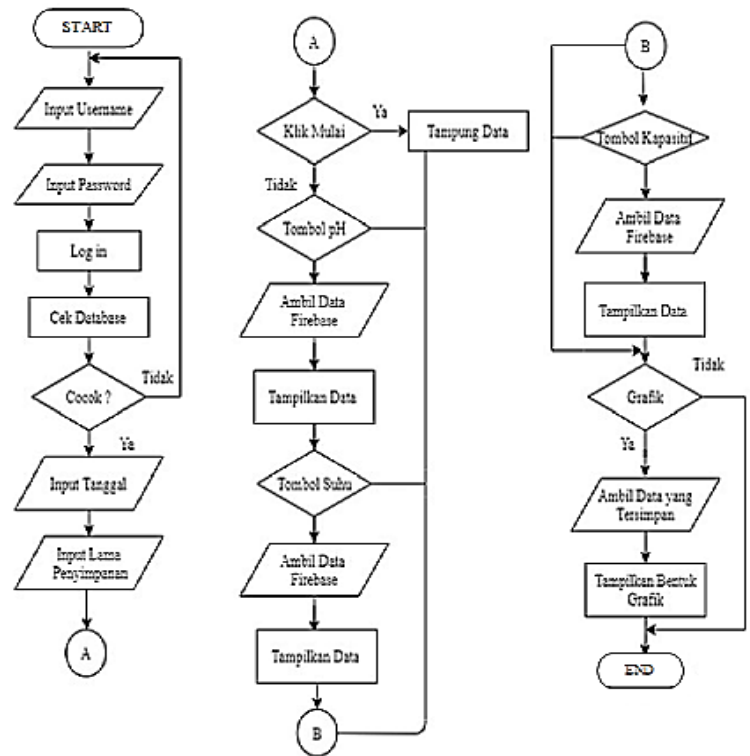

Gambar 4. Flowchart Aplikasi Android 
Gambar 4. menjelaskan tentang alur proses pada perencanaan aplikasi dimulai dari pengguna android memasukan kode dan pasword. Jika username dan password tidak cocok maka akan kembali mengulang ke proses login, tetapi jika password cocok maka akan masuk pada halaman menu atur waktu penyimpanan terdapat untuk menginputkan tanggal saat pengambilan data dan waktu lama penyimpanan. Selanjutnya pengguna masuk pada halaman menu deteksi yang terdapat button mulai untuk menyimpan data dari keluaran sensor yang akan ditampilkan dalam bentuk grafik dan klik stop untuk mengakhiri sehingga bisa dilihat dengan menekan pada button grafik. Pengguna juga bisa menekan button pada sensor $\mathrm{pH}$, suhu, dan kapasitif untuk melihat berapa nilai keluaran dari sensor.

\section{Perancangan Hardware}

Gambar 5. dibuat desain prototype box untuk penempatan sensor dengan akrilik ukuran $55 \mathrm{~cm}$ x $25 \mathrm{~cm}$ x $20 \mathrm{~cm}$ dan dengan ketebalan akrilik $2 \mathrm{~mm}$. Desain box terdapat 3 sensor yang terdiri dari sensor $\mathrm{pH}$, suhu dan sensor kapasitif, mikrokontroller, juga akrilik sebagai penyangga sensor kapasitif. Pada prototype ini dibuat sekat pemisah antara penempatan sensor dan Mikrokontroller. Mikrokontroller Arduino Uno sebagai pemroses data dari sensor, dan Modul ESP8266 untuk perangkat transmisi data hasil pengolahan Arduino secara wireless ke Android.

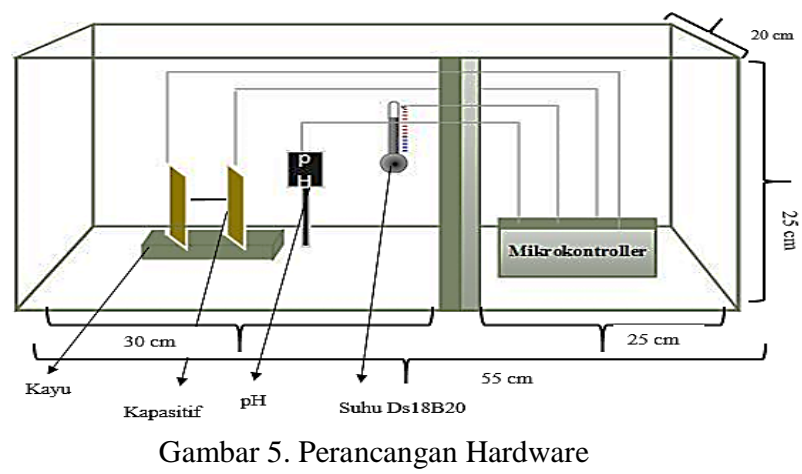

E. Desain Aplikasi

Layout desain aplikasi pada penelitian ini diperlihatkan pada gambar 6 .
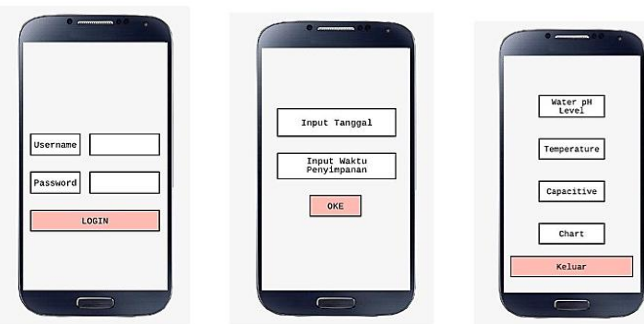

Gambar 6. Desain aplikasi android

\section{HASIL DAN PEMBAHASAN}

Uji coba yang dilakukan bertujuan untuk memastikan bahwa sensor yang ada pada Arduino Uno bekerja dengan baik selain itu juga ada uji coba untuk memastikan bahwa kondisi sistem juga berjalan dengan baik. Berikut pengujian yang telah dilakukan:

\section{A. Pengujian kalibrasi sensor $\mathrm{pH}$}

Pengujian sensor $\mathrm{pH}$ bertujuan untuk mengetahui tingkat keakurasian data yang terbaca oleh sensor terhadap hasil kalibrasi sensor menggunakan alat ukur. Proses pengambilan data kalibrasi dilakukan dengan menggunakan $\mathrm{pH}$ buffer powder dan alat ukur $\mathrm{pH}$ meter. Proses pengujian kalibrasi sensor $\mathrm{pH}$ ada pada gambar 7

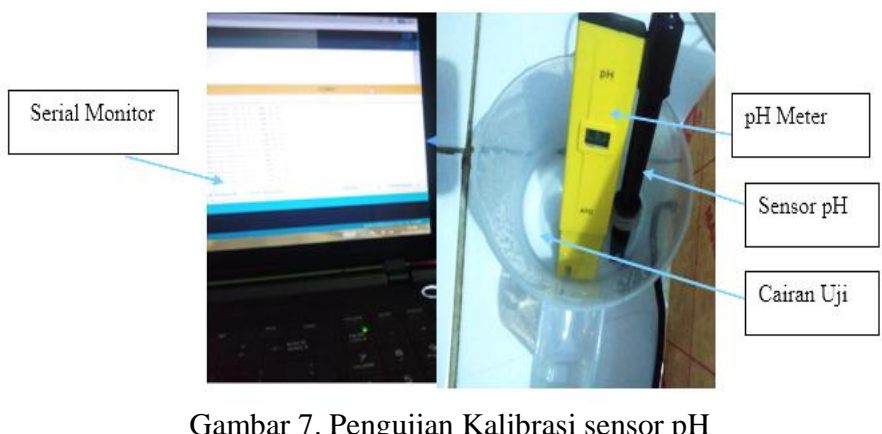

Langkah pertama yang dilakukan untuk mengukur kadar $\mathrm{pH}$ yaitu menggunakan sampel larutan $\mathrm{pH}$. Sampel ini terdiri dari 2 sampel berbeda yaiu air yang dilarutkan pada ph buffer powder 4.00 dan pada buffer powder 6.86. langkah selanjutnya yaitu menyiapkan $\mathrm{pH}$ meter dan sensor ph kedalam larutan $\mathrm{ph}$ buffer. Selanjutnya membandingkan hasil yang terukur pada sensor $\mathrm{pH}$ dan alat ukur. Data hasil sampel ditunjuukan pada tabel 1:

Tabel 1 Hasil kalibrasi Sensor $\mathrm{pH}$

\begin{tabular}{|l|l|l|l|l|}
\hline No & Cairan uji & $\begin{array}{l}\text { pH } \\
\text { meter }\end{array}$ & $\begin{array}{l}\text { Sensor } \\
\text { pH }\end{array}$ & $\begin{array}{l}\text { Deviasi } \\
\text { eror \% }\end{array}$ \\
\hline 1. & $\begin{array}{l}\text { pH buffer powder } \\
4.00\end{array}$ & 4.0 & 3.98 & 0.005 \\
\hline 2. & $\begin{array}{l}\text { pH buffer powder } \\
6.86\end{array}$ & 6.9 & 6.93 & 0.0043 \\
\hline
\end{tabular}

Dalam pengujian ini Perhitungan nilai deviasi eror pada table 1 didapatkan dengan rumus berikut

Deviasi eror $\%=\frac{(\text { nilai } p H \text { meter }- \text { Nilai sensor } p H)}{\text { nilai } p H \text { meter }} X 100 \%$

Dalam kalibrasi ini alat ukur pH meter untuk membaca kadar $\mathrm{pH}$ yang terlarut dalam masing-masing sampel air. Dalam pengujian ini, $\mathrm{pH}$ meter yang digunakan adalah $\mathrm{pH}$ meter ATC yang mempunyai tingkat akurasi $0.1 \mathrm{pH}$.

\section{B. Pengujian kalibrasi sensor Suhu DS18B20}

Pengujian sensor suhu bertujuan untuk mengetahui tingkat keakurasian data yang terbaca oleh sensor terhadap hasil 
kalibrasi sensor menggunakan alat ukur. Proses pengambilan data kalibrasi dilakukan dengan menggunakansensor suhu DS18B20 dan thermometer Hygrometer. Proses pengujian kalibrasi sensor suhu ada pada gambar 8 .

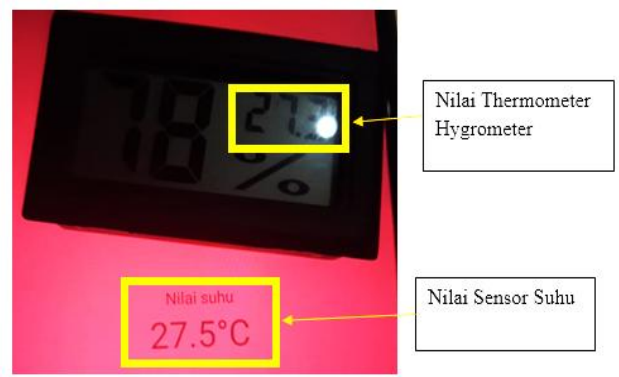

Gambar 8. Proses Pengujian Kalibrasi sensor Suhu

Langkah pertama yang dilakukan untuk mengukur suhu yang digunakan kalibrasi dari sensor suhu yaitu memastikan bahwa alat thermometer Hygromether dakam keadaan ON. Selanjutnya dengan membandingkan keluaran hasil sensor di android dan thermomether Hygromether yang terbaca. Data hasil sampel ditunjuukan pada tabel 2 berikut:

Tabel 2 Hasil Kalibrasi Sensor Suhu

\begin{tabular}{|c|c|c|c|}
\hline No. & $\begin{array}{c}\text { Nilai Sensor } \\
\text { DS18B20 }\end{array}$ & $\begin{array}{c}\text { Nilai } \\
\text { Thermometer } \\
\text { Hygrometer }\end{array}$ & $\begin{array}{c}\text { Deviasi } \\
\text { Eror \% }\end{array}$ \\
\hline 1. & $27.0^{\circ} \mathrm{C}$ & $27.3^{\circ} \mathrm{C}$ & 0.010 \\
\hline 2. & $27.5^{\circ} \mathrm{C}$ & $27.5^{\circ} \mathrm{C}$ & 0 \\
\hline 3. & $27.5^{\circ} \mathrm{C}$ & $27.3^{\circ} \mathrm{C}$ & 0.007 \\
\hline 4. & $27.0^{\circ} \mathrm{C}$ & $27.5^{\circ} \mathrm{C}$ & 0.018 \\
\hline 5. & $26.0^{\circ} \mathrm{C}$ & $26.8^{\circ} \mathrm{C}$ & 0.029 \\
\hline 6. & $26.0^{\circ} \mathrm{C}$ & $26.9^{\circ} \mathrm{C}$ & 0.033 \\
\hline 7. & $27.0^{\circ} \mathrm{C}$ & $27.3^{\circ} \mathrm{C}$ & 0.010 \\
\hline 8. & $29.0^{\circ} \mathrm{C}$ & $28.8^{\circ} \mathrm{C}$ & 0.006 \\
\hline 9. & $29.5^{\circ} \mathrm{C}$ & $29.2^{\circ} \mathrm{C}$ & 0.010 \\
\hline 10. & $29.0^{\circ} \mathrm{C}$ & $29.5^{\circ} \mathrm{C}$ & 0.016 \\
\hline Rata-rata & & 0.0139 \\
\hline
\end{tabular}

Dalam pengujian ini Perhitungan nilai eror pada tabel 2 deviasi eror didapatkan dengan rumus (1). Rata-rata Deviasi eror dengan 10 kali percobaan adalah $0.0139 \%$ sehingga dapat dikatakan bahwa sensor DS18B20 dapat bekerja dengan baik karena nilai eror relative kecil.

A. Hasil Rangkaian Hardware

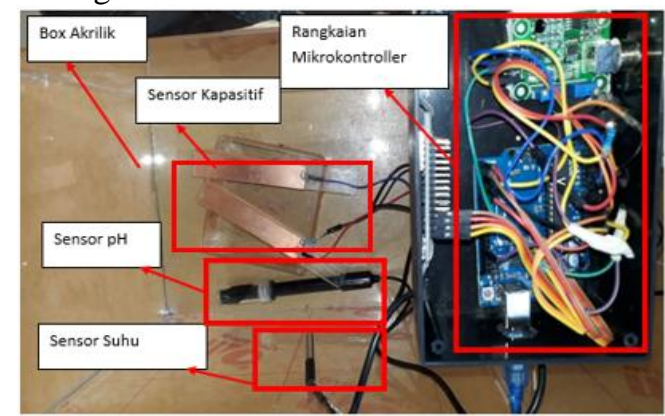

Gambar 9. Hasil Rangkaian Hardware
Gambar 9 merupakan hasil rangkaian hardware dari alat yang telah diimplementasikan. Perangkat pada sistem ini terdiri atas Arduino Uno sebagai mikrokontroller serta perangkat input yang terhubung dengan mikrokontroller terdiri atas sensor $\mathrm{pH}$, sensor suhu, sensor kapasitif dan perangkat output terdiri atas modul ESP8266 dan android untuk menampilkan hasil data. Komponen-komponen dalam sistem ini akan dihubungkan menggunakan kabel pelangi dengan header sesuai perancangan. Selanjutnya dengan menggunakan powerbank sebagai daya pada arduino. Setiap komponen yang terpasang kemudian ditata didalam sebuah box.

\section{B. Hasil Implementasi Software Aplikasi}

Untuk membuat aplikasi Android digunakan software Android studio. Fungsi dari dibuatnya aplikasi ini digunakan untuk mengetahui informasi data hasil dari sensor, selain itu pengguna juga dapat mengetahui grafik data keluaran sensor jika ditekan tombol mulai. Sehingga dimanapun keberadaan pengguna tersebut dapat memenatau hasil data sensor. Berikut adalah tampilan aplikasi android

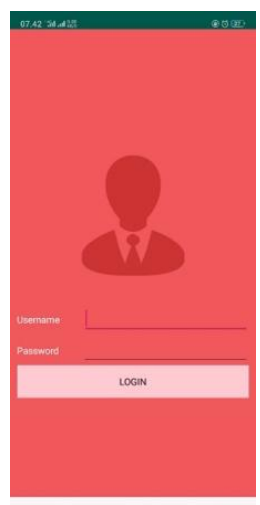

(a)

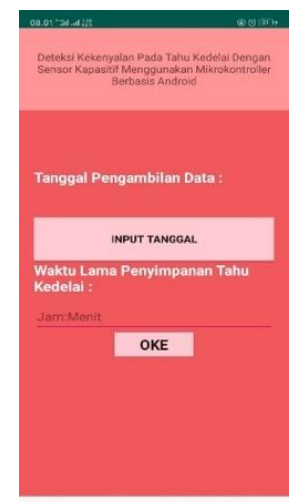

(b)

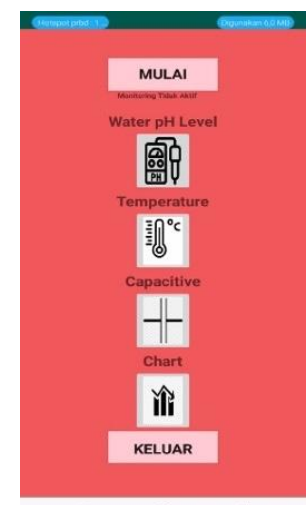

(c)
Gambar 10. (a) Halaman Awal Pada, (b) halaman simpan, (c) halaman menu pada Aplikasi Android

Gambar 10(a) menunjukkan halaman home (utama) pada aplikasi. Untuk dapat menggunakan aplikasi ini kita hanya perlu menginstall aplikasi ini. Untuk log in ke aplikasi harus memasukkan username dan pasword yang sudah ditentukan.

Gambar 10(b) menunjukkan halaman menu setting atur waktu untuk pengambilan data dan waktu penyetingan lama penyimpanan tahu kedelai. Terdapat kolom input waktu, button oke untuk memulai waktu yang telah diinputkan dan selanjutnya ada alarm yang menandakan waktu inputan sudah selesai.

Gambar 10(b) menunjukkan beberapa menu untuk keluaran nilai dari sensor yang akan dilihat hasil melalui aplikasi. Jika dipilih menu mulai maka otomatis akan membuat grafik keluaran nilai dari sensor, $\mathrm{pH}$, suhu, kapasitif selanjutnya button stop untuk menghentikan hasil keluaran nilai dari semua sensor dan bisa di tampilkan dengan menekan menu grafik. 
Pada halaman ini pengguna juga bisa memilih menu lainya dengan menekan menu gambar $\mathrm{pH}$ maka akan menampilkan nilai kadar $\mathrm{pH}$, jika pengguna memilih menu gambar suhu maka akan menampilkan nilai suhu ruang yang berada dalam box, jika pengguna memilih menu kapasitif maka akan muncul nilai kapasitif dari tahu kedelai yang diukur.

\section{Pengujian Sensor $\mathrm{pH}$}

Berdasarkan table 3 pengujian $\mathrm{pH}$ dapat diketahui bahwa perbandingan nilai sensor $\mathrm{pH}$ dengan $\mathrm{pH}$ meter ini memiliki nilai yang berdekatan dengan mengambil data sebanyak 5 sampel, pengujian satu sampel selama 30 menit dengan melakukan percobaan sebanyak 3 kali pengulangan dalam satu sampel. Dengan cara mendiamkan alat uji $\mathrm{pH}$ meter dan sensor $\mathrm{pH}$ didalam sampel yang digunakan untuk mendapatkan tingkat deviasi eror pada sensor. Hasil tingkat pembacaan $\mathrm{pH}$ yang mendekati pada nilai $\mathrm{pH}$ pada tahu kedelai pabrik $\mathrm{ABC}$ dapat dilihat terdapat pada pengujian $\mathrm{pH}$ cuka pada makanan.

Tabel 3. Pengujian Sensor $\mathrm{pH}$

\begin{tabular}{|c|c|c|c|c|c|c|}
\hline $\begin{array}{l}\text { Percobaan } \\
\text { ke- }\end{array}$ & $\begin{array}{l}\text { Waktu } \\
\text { / menit }\end{array}$ & Sampel & $\begin{array}{l}\text { Ph } \\
\text { mete } \\
\text { r }\end{array}$ & $\begin{array}{l}\text { Senso } \\
\text { r pH }\end{array}$ & $\begin{array}{l}\text { Selisi } \\
\text { h } \\
\text { nilai }\end{array}$ & $\begin{array}{l}\text { Devias } \\
\text { i } \\
\text { eror } \\
\%\end{array}$ \\
\hline 1. & 10 & \multirow{3}{*}{$\begin{array}{l}\text { cuka } \\
\text { asam } \\
\text { tahu } \\
\text { dipabri } \\
\text { k ABC }\end{array}$} & 3.1 & 3.18 & 0.08 & 0.025 \\
\hline 2. & 20 & & 3.1 & 3.16 & 0.06 & 0.019 \\
\hline 3. & 30 & & 3.3 & 3.68 & 0.38 & 0.115 \\
\hline 1. & 10 & \multirow{3}{*}{$\begin{array}{l}\text { cuka } \\
\text { asam } \\
\text { untuk } \\
\text { makan } \\
\text { an }\end{array}$} & 3.2 & 3.18 & 0.02 & 0.006 \\
\hline 2. & 20 & & 3.3 & 3.21 & 0.09 & 0.027 \\
\hline 3. & 30 & & 3.4 & 3.49 & 0.09 & 0.026 \\
\hline 1. & 10 & \multirow{3}{*}{$\begin{array}{l}\text { Yogou } \\
\mathrm{rt}\end{array}$} & 3.5 & 3.49 & 0.01 & 0.002 \\
\hline 2. & 20 & & 3.4 & 3.46 & 0.06 & 0.017 \\
\hline 3. & 30 & & 3.4 & 3.57 & 0.17 & 0.05 \\
\hline 1. & 10 & \multirow{3}{*}{$\begin{array}{l}\text { Air } \\
\text { kelapa }\end{array}$} & 4.2 & 4.31 & 0.11 & 0.026 \\
\hline 2. & 20 & & 4.2 & 4.39 & 0.19 & 0.045 \\
\hline 3. & 30 & & 4.2 & 4.28 & 0.08 & 0.019 \\
\hline 1. & 10 & \multirow{3}{*}{ kecap } & 3.9 & 3.90 & 0 & 0 \\
\hline 2. & 20 & & 3.9 & 4.01 & 0.11 & 0.028 \\
\hline 3. & 30 & & 4.0 & 4.09 & 0.09 & 0.022 \\
\hline
\end{tabular}

\section{Hasil dan Analisa Pengujian Pada Sistem}

Pengujian ini diambil pada pabrik tahu ABC dikota Malang dengan menggunakan 3 sensor yaitu $\mathrm{pH}$, suhu dan kapasitif. Sensor $\mathrm{pH}$ untuk mengetahui berapa tingkat $\mathrm{pH}$ yang digunakan untuk pembuatan tahu, sensor suhu untuk mengetahui berapa suhu ruang untuk penyimpanan dan sensor kapasitif untuk mengetahu nilai kapasitansi dari tahu kedelai sebagai bahan dielektrik dengan menggunakan 2 plat PCB dengan ukuran plat $2 \mathrm{~cm} \times 10 \mathrm{~cm}$ dan diameter $1.5 \mathrm{~cm} 3$ sampel tahu yang berbeda yaitu jenis tahu lembek, kenyal dan keras. Langkah pertama yang harus dilakukan untuk pengambilan data adalah ukur berapa kadar asam yang akan dipakai untuk pembuatan tahu kedelai dengan sensor $\mathrm{pH}$, menyiapkan 3 sampel tahu yang akan diuji dan melakukan pengujian menggunakan sensor kapasitif. Hasil pengujian akan masuk ke firebase dan ditampilkan pada android. Proses pengujian sensor ini di tunjukkan pada gambar 14 berikut:

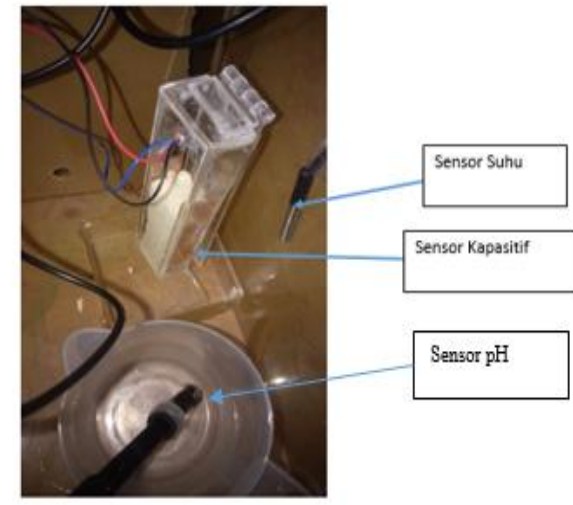

Gambar 11 Proses Pengujian Sistem

Hasil pengujian dari gambar 11 ditunjukkan pada tabel 3 berikut:

\begin{tabular}{|c|c|c|c|c|}
\hline Hari Ke & $\begin{array}{l}\text { Jenis } \\
\text { Tahu }\end{array}$ & pH & Suhu & Kapasitif \\
\hline \multirow[t]{3}{*}{1} & Lembek & \multirow{3}{*}{4.56} & \multirow{3}{*}{$29.0^{\circ} \mathrm{C}$} & $6.1 \mu \mathrm{F}$ \\
\hline & Kenyal & & & $3.58 \mu \mathrm{F}$ \\
\hline & Keras & & & $1.88 \mu \mathrm{F}$ \\
\hline \multirow[t]{3}{*}{2} & Lembek & \multirow{3}{*}{4.48} & \multirow{3}{*}{$28.5^{\circ} \mathrm{C}$} & $5.5 \mu \mathrm{F}$ \\
\hline & Kenyal & & & $3.27 \mu \mathrm{F}$ \\
\hline & Keras & & & $1.7 \mu \mathrm{F}$ \\
\hline \multirow[t]{3}{*}{3} & Lembek & \multirow{3}{*}{3.8} & \multirow{3}{*}{$27.0^{\circ} \mathrm{C}$} & $6.55 \mu \mathrm{F}$ \\
\hline & Kenyal & & & $3.10 \mu \mathrm{F}$ \\
\hline & Keras & & & $2.77 \mu \mathrm{F}$ \\
\hline \multirow[t]{3}{*}{4} & Lembek & \multirow{3}{*}{4.10} & \multirow{3}{*}{$26.0^{\circ} \mathrm{C}$} & $5.90 \mu \mathrm{F}$ \\
\hline & Kenyal & & & $3.45 \mu \mathrm{F}$ \\
\hline & Keras & & & $1.5 \mu \mathrm{F}$ \\
\hline \multirow[t]{3}{*}{5} & Lembek & \multirow{3}{*}{4.30} & \multirow{3}{*}{$26.5^{\circ} \mathrm{C}$} & $6.2 \mu \mathrm{F}$ \\
\hline & Kenyal & & & $3.33 \mu \mathrm{F}$ \\
\hline & Keras & & & $2.55 \mu \mathrm{F}$ \\
\hline
\end{tabular}

Berdasarkan tabel 4 dapat diketahui bahwa hasil pengujian yang dilakukan pada Pabrik ABC dikota Malang dengan 5 hari pengujian dengan hasil penggunaan sensor $\mathrm{pH}$ sangat bagus dikarenkankan kadar $\mathrm{pH}$ yang digunakan pada pembuatan tahu berkisar 3-4. Pengujian dengan memanfaatkan sensor kapasitif mendapatkan nilai kapasitansi kekenyalan tertinggi yaitu sebesar 3.58 dengan kadar $\mathrm{pH}$ yang digunakan 4.56 dengan menggunakan suhu penyimpanan $29.0^{\circ} \mathrm{C}$ terdapat pengujian pada hari ke-1.Pada pengujian ini untuk menentukan jenis tahu dengan kualitas yang keras ditambahkan 1 sendok CHS04 pada pH sedangkan untuk tahu dengan kualitas lembek dikarenakan oleh faktor perendaman pada kedelai terlalu lama yang mengakibatkan kualitastahu kedelai menjadi lembek atau gagal. 
E. Pengujian Jaringan Untuk Pengiriman Data Delay

Pengujian Quality of Server (QoS) bertujuan untuk mengetahui performansi sistem dengan mengukur beberapa parameter yaitu delay, throughput. Pengujian dilakukan menggunakan koneksi jaringan wifi yang terhubung pada internet. Untuk software yang digunakan adalah wireshark.

Tabel 5. Pengujian Delay

\begin{tabular}{|c|c|c|}
\hline NO & Source & Delay \\
\hline 1 & 192.168 .43 .119 & 0 \\
\hline 2 & 192.168 .43 .119 & 1.586 \\
\hline 3 & 192.168 .43 .119 & 2.449 \\
\hline 4 & 192.168 .43 .119 & 0.681 \\
\hline 5 & 192.168 .43 .119 & 1.522 \\
\hline 6 & 192.168 .43 .119 & 0.017 \\
\hline 7 & 192.168 .43 .119 & 1.471 \\
\hline 8 & 192.168 .43 .119 & 1.398 \\
\hline 9 & 192.168 .43 .119 & 0.909 \\
\hline 10 & 192.168 .43 .119 & 2.659 \\
\hline 11 & 192.168 .43 .119 & 1.469 \\
\hline 12 & 192.168 .43 .119 & 0.880 \\
\hline 13 & 192.168 .43 .119 & 3.743 \\
\hline 14 & 192.168 .43 .119 & 0.366 \\
\hline 15 & 192.168 .43 .119 & 4.248 \\
\hline 16 & 192.168 .43 .119 & 0.773 \\
\hline 17 & 192.168 .43 .119 & 2.596 \\
\hline 18 & 192.168 .43 .119 & 0.019 \\
\hline
\end{tabular}

Delay adalah waktu yang diperlukan suatu paket untuk sampai ke tujuan. Untuk software yang digunakan adalah wireshark. Pada gambar 12 merupakan grafik sampel 18 paket yang akan dicari rata - rata dari delay, paket tersebut diambil pada wireshark yang terdiri dari beberapa paket ketika melakukan pengiriman data. Semakin kecil delay maka akan semakin bagus kualitas suatu panggilan karena tidak akan terjadi keterlambatan informasi.

\section{F. Pengujian Jaringan Untuk Pengiriman Data Troughput}

Gambar 12: Tampilan troughput pada wireshark

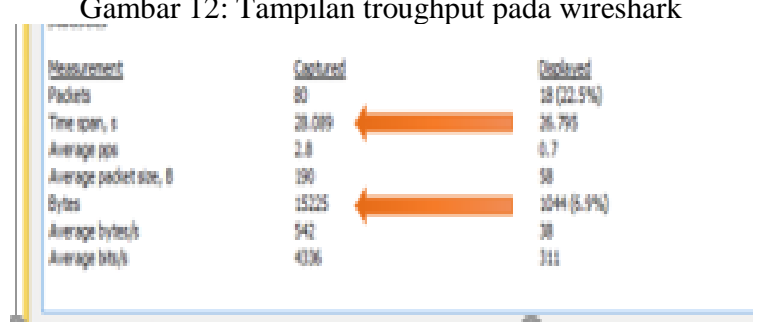

Rumus troughput

$$
\begin{aligned}
\text { Troughput } & =\frac{\text { Bytes }}{\text { Time span, } \mathrm{s}} \times 8 \\
\text { Throghput } & =\frac{15225}{28.089} \times 8 \\
& =4336.217 \mathrm{~b} / \mathrm{s}
\end{aligned}
$$

\section{KESIMPULAN}

Nilai $\mathrm{pH}$ berkisar 3-4 yang menandakan kadar $\mathrm{pH}$ yang digunakan sangat bagus untuk dipakai pada pengolahan tahu, pada pH 4.56 mendapatkan nilai kapasitansi kekenyalan paling tinggi sebesar 3.58 dengan suhu ruang $29^{\circ} \mathrm{C}$ pada pengambilan sampel tahu hari ke-1 pada pabrik ABC kota Malang.

Dari pengujian pengiriman data didapatkan nilai delay paling kecil $0.017 \mathrm{~ms}$ dan nilai paling besar $4.248 \mathrm{~ms}$. Pada pecobaan ini didapatkan rata-rata delay sebesar $1.488 \mathrm{~ms}$ yang terdapat pada standarisasi TIPHON indeks ke-4 yang artinya dalam kategori sangat bagus. Dengan demikian dapat dikatakan bahwa semakin kecil nilai delay maka kualitas pengiriman data semakin baik karena tidak akan terjadi keterlambatan pengiriman data.Hasil dari pengujian sistem dapat mengirim data secara langsung setiap pengukuran dan keberhasilan pengiriman data dengan diperoleh nilai troughtput sebesar $4336.217 \mathrm{~b} / \mathrm{s}$ yang termasuk dalam kategori jelek.

\section{REFERENSI}

[1] C. Satria, M. N. Zakaria, and F. A. Soelistianto, "Design of Palm Cooking Oil Quality Detector Using Ultrasonic Sensor Methods and Capacitive Sensors based on Smartphone", Jartel, vol. 10, no. 3, pp. 140-143, Sep. 2020

[2] T. A. Wicaksono, A. Hariyadi, and K. Koesmarijanto, "Implementation of a Temperature Control System in the Roasting Process of Cilembu Sweet Potatoes Using a Microcontroller Based Oven”, Jartel, vol. 10, no. 3, pp. 136-139, Sep. 2020.

[3] Rahmadwati, S.T., M.T., Dyah Ayu Anggreini T., Ir. Retnowati, M.T. "Pengendalian Kadar Keasaman (PH) Pada Pengendapan Tahu Menggunakan Kontroler PID Berbasis ATmega328." Jurnal Mahasiswa Teknik Elektro Universitas Brawijaya, vol. 2, no. 6, 2014.

[4] N. D. G. S. T. M. R. S. Shanti, "Identifikasi sifat dielektrik pisang pada tingkat kematangan berbeda dengan rangkaian RLC," Radiasi, vol. 06, no. 02, pp. 1-7, 2015.

[5] Y. Irana, W. Waluyo, and M. N. Zakaria, "Design of Cooling Temperature in the Jacket Using an Android-Based Microcontroller", Jartel, vol. 11, no. 1, pp. 23-26, Mar. 2021.

[6] W. Puspitasari and H. Y. Perdana R, "Real-Time Monitoring and Automated Control of Greenhouse Using Wireless Sensor Network: Design and Implementation," 2018 International Seminar on Research of Information Technology and Intelligent Systems (ISRITI), 2018, pp. 362-366, doi 10.1109/ISRITI.2018.8864377.

[7] R. H. Y. Perdana, H. Hudiono and A. F. N. Luqmani, "Water Leak Detection and Shut-Off System on Water Distribution Pipe Network Using Wireless Sensor Network," 2019 International Conference on Advanced Mechatronics, Intelligent Manufacture and Industrial Automation (ICAMIMIA), 2019, pp. 297-301, doi: 10.1109/ICAMIMIA47173.2019.9223386.

[8] H. Hudiono, M. Taufik, R. H. Y. Perdana, and W. R. Rohmah, "Design and implementation of centralized reading system on analog postpaid water meter," in IOP Conference Series: Materials Science and Engineering, 2020, vol. 732, no. 1.

[9] M. Taufik, A. E. Rakhmania, and Y. N. Afnani, "Prepaid water meter card based on internet of things," in IOP Conference 
Series: Materials Science and Engineering, 2020, vol. 732, no.

1, pp. 1-7. 